\title{
New cryptic species of Teratosphaeria on Eucalyptus in Australia
}

\author{
Vera Andjic ${ }^{1}$, Aaron Maxwell ${ }^{1}$, Giles E. StJ. Hardy ${ }^{1}$, and Treena I. Burgess ${ }^{1,2}$
}

'School of Veterinary and Life Sciences, Murdoch University, South St, Murdoch, 6150, Australia; corresponding author e-mail: v.andjic@ murdoch.edu.au

${ }^{2}$ Forestry and Agricultural Biotechnology Institute (FABI), University of Pretoria, Pretoria 0002, South Africa

Abstract: Teratosphaeria destructans and T. viscida are serious pathogens causing leaf, bud and shoot blight diseases of Eucalyptus plantations in the subtropics and tropics of South-East Asia ( $T$. destructans) and North Queensland, Australia (T. viscida). During disease surveys in northern Western Australia and the Northern Territory of Australia, symptoms resembling those of $T$. destructans were observed on young and adult leaves of native and plantation Eucalyptus spp. and its hybrids. Phylogenetic studies revealed Teratosphaeria species associated with these symptoms are new taxonomic novelties described here as $T$. novaehollandiae and $T$. tiwiana spp. nov. Isolates from previous records of $T$. destructans recorded in Australia were re-examined and based upon the phylogenetic evidence are reassigned to these new taxa. We conclude that $T$. destructans is absent from Australia.
Key words: biosecurity DNA phylogeny Kirramyces

Article info: Submitted: 25 February 2016; Accepted: 6 October 2016; Published: 20 October 2016.

\section{INTRODUCTION}

Teratosphaeria leaf diseases (TLD; Crous et al. 2006, Hunter et al. 2006, Crous 2009, Crous et al. 2009a, b) have emerged as significant foliar diseases impacting on the eucalypt plantation industry in subtropical and tropical areas of Australia (Carnegie et al. 2007a, b, c). Teratosphaeria species with kirramyces-like asexual morphs have emerged as the most significant foliar pathogens of this genus; namely $T$. destructans, T. eucalypti, T. pseudoeucalypti, T. suttonii, and T. viscida (Wingfield et al. 1996, Park et al. 2000, Carnegie 2007a, b, Andjic et al. 2010a). These five species cause a serious leaf blight disease, leading to premature defoliation and in some instances tree mortality (Andjic et al. 2007b, 2010a, Carnegie 2007a, b, c). Symptoms are similar and include brown to purple spots on leaves with diffuse border and red brown margin, necrotic lesions delimited by veins and presence of spore masses and conidia (Dick 1982, Walker et al. 1992, Wingfield et al. 1996, Burgess et al. 2006, Andjic et al. 2007a, b, c, Andjic et al. 2010a). Conidia of these species are all long, variously curved, subhyaline to pale brown, smooth to verruculose and are virtually indistinguishable by morphology (excluding T. suttonii), thus making diagnostics based on morphology impossible (Andjic et al. 2010b, Hunter et al. 2011).

Teratosphaeria destructans is an aggressive pathogen causing a leaf, bud and shoot blight disease (Wingfield et al. 1996). This pathogen was first discovered in Indonesia in 1996 and has since been detected in Thailand, China, Vietnam, and most recently South Africa (Burgess et al. 2006, Old et al. 2003a, b, Wingfield et al. 1996, Greyling et al. 2016). In Australia, T. destructans is only reported from
Tiwi Island in the Northern Territory (on introduced plantation Eucalyptus hybrids) and Derby in Western Australia (on amenity Eucalyptus sp.) (Burgess et al. 2007). Teratosphaeria eucalypti is a leaf parasite of endemic Eucalyptus species (eastern Australia) but under favourable conditions can cause a serious leaf blight disease mostly infecting juvenile leaves of some Eucalyptus species in plantations (Carnegie 2007b). Teratosphaeria eucalypti is known to have been introduced with plantings of $E$. nitens from Australia into New Zealand, where it has resulted in complete defoliation of juvenile leaves of E. nitens (Dick 1982, Miller et al. 1992). Teratosphaeria pseudoeucalypti was first discovered on an unidentified Eucalyptus sp. and hybrids of E. grandis $\times$ camaldulensis in Central Queensland, where it caused severe outbreaks and damage (Andjic et al. 2010a). Since then the pathogen has been detected in Argentina (Ramos \& Perez 2015), Brazil (de Souza et al. 2014), and Uruguay (Soria et al. 2014). Teratosphaeria suttonii is known from many countries (Park et al. 2000, Sankaran et al. 1995, Taole et al. 2015) and can cause severe damage in eucalypt plantations (Carnegie 2007b). Teratosphaeria viscida was first detected in 2005 causing leaf and shoot blight in E. grandis and complete defoliation of $E$. grandis $\times$ camaldulensis hybrids in Mareeba, North Queensland (Andjic et al. 2007b).

Whilst T. eucalypti, T. pseudoeucalypti, T. suttonii, and T. viscida are all native to Australia, the origin of $T$. destructans is still unclear (Andjic et al. 2011). Based on DNA sequence variation of Australian isolates, it was thought that $T$. destructans originated from Australia (Burgess et al. 2007). Teratosphaeria destructans was a high risk pathogen for Australia and was on the Northern Australia Quarantine Strategy (NAQS) biosecurity target list (as Kirramyces

() 2016 International Mycological Association

You are free to share - to copy, distribute and transmit the work, under the following conditions:

Attribution: $\quad$ You must attribute the work in the manner specified by the author or licensor (but not in any way that suggests that they endorse you or your use of the work).

Non-commercial: You may not use this work for commercial purposes.

No derivative works: You may not alter, transform, or build upon this work.

For any reuse or distribution, you must make clear to others the license terms of this work, which can be found at http://creativecommons.org/licenses/by-nc-nd/3.0/legalcode. Any of the above conditions can be waived if you get permission from the copyright holder. Nothing in this license impairs or restricts the author's moral rights. 
destructans), but later removed after being reported in northern Australia by Burgess et al. (2007) (Jane Ray pers. comm.).

During surveys of native and plantation eucalypt species in northern Western Australia and the north-western Northern Territory over the years 2006-12, we observed leaves exhibiting symptoms similar to those of $T$. destructans. Samples were collected across several sites and preliminary examination revealed a fungus with a conidial morphology similar to that of $T$. destructans. This study describes two new species of Teratosphaeria with long conidia found in northern Western Australia and the Northern Territory that are distinct from T. destructans.

\section{MATERIALS AND METHODS}

\section{Collection and isolation}

Eucalypt leaves with symptoms resembling those of Teratosphaeria destructans were collected from several different locations in Australia: (a) adult mature trees of a Eucalyptus sp. in Derby, Western Australia; (b) juvenile leaves from Eucalyptus hybrids in plantations on Tiwi Island, Northern Territory; and (c) juvenile and adult foliage from eucalypt woodlands at several locations in northern, Western Australia and north-western parts of Northern Territory (Table 1, Fig. 1C). Isolations were made as described previously (Andjic et al. 2007 a). Isolates are maintained in culture collections at Murdoch University, Perth, Western Australia (MUCC) and the Department of Agriculture and Water Resources (AQISWA), Perth, Western Australia. Ex-type cultures and leaf material have been deposited in the fungal collection of Queensland Plant Pathology Herbarium (BRIP), Brisbane, Queensland, Australia, and the KNAW-CBS Fungal Biodiversity Centre (CBS), Utrecht, The Netherlands.

\section{Morphological identification and characterisation}

Preliminary identification of the Teratosphaeria isolates was by microscopic examination and culturing. Plugs $(2 \mathrm{~mm}$ diam) were cut from actively growing cultures and placed at the centres of Petri dishes (55 mm diam) containing $2 \%$ Malt Extract Agar (MEA). After $30 \mathrm{~d}$, cultures were assessed for growth-rate, by taking two measurements of colony diameter perpendicular to each other. Colony colour was described using notations in the Munsell $®$ Soil Colour Charts (Gretag Macbeth, New Windsor, NY, revised 2000).

Squash mounts of sporing structures were prepared, from hand sections of lesions and from culture, on slides in lacto-glycerol (1:1:1 v lactic acid: glycerol: water) and observed at 1000x magnification with Leica DM5000 light microscope. Morphological characters used in this study to distinguish Teratosphaeria species producing kirramyceslike long conidia included: conidial size, shape, pigmentation and number of septa. Wherever possible, 30 measurements of all potentially taxonomically relevant structures were recorded for each species and the extremes are presented in parentheses. Measurements of conidial size were obtained using image analysis software Leica Image Application Suite (LAS) and adjusted to the nearest $0.5 \mu \mathrm{m}$. Conidium lengths were recorded as straight-line (linear) length following the method of previous studies of Teratosphaeria (Wingfield et al. 1996). Data analyses were performed using descriptive statistics in Microsoft Excel.

\section{DNA Extraction, PCR amplification and sequencing}

Isolates were grown on $2 \% \mathrm{MEA}$ at $20^{\circ} \mathrm{C}$ for $4 \mathrm{wk}$ and the mycelium was harvested and placed in a $1.5 \mathrm{~mL}$ sterile Eppendorf $®$ tube. Harvested mycelium was ground to a fine powder using cordless motor pellet pestle (Sigma-Aldrich) and genomic DNA was extracted using a DNeasy ${ }^{\circledR}$ Plant Mini Kit (Qiagen) following the manufacturer's instructions. ITS2 and part of the 5.8S region of the rDNA (ITS2), and two partial protein-coding genes, $\beta$-tubulin (tub2) and translation elongation factor (tef1), were sequenced for all isolates as described previously (Andjic et al. 2007a).

\section{Phylogenetic analysis}

The phylogeny of the new Teratosphaeria isolates was estimated using parsimony and maximum likelihood methods. In order to compare Teratosphaeria species used in this study with other closely related species, additional ITS2, tub2 and tef1 sequences were obtained from GenBank (Table 1). Sequence data were assembled and aligned using the CLUSTALW algorithm implemented in Geneious R7 v. 7.0.4 (Biomatters). Adjustments to the alignments were made manually by inserting gaps where necessary.

Maximum parsimony analyses were performed on individual (data not shown) and combined data sets in PAUP (Phylogenetic Analysis Using Parsimony) v. 4.0b10 (Swofford 2003) after a partition homogeneity test (PHT) of the combined ITS2, tub2 and tef1 alignments was conducted in PAUP (Phylogenetic Analysis Using Parsimony) v. 4.0b10 (Swofford 2003) to test pairwise congruence between the sequence data sets.

The equally most parsimonious trees were obtained using heuristic searches with random stepwise taxon additions in 100 replicates, with the tree bisection-reconnection branchswapping option on and the steepest-descent option off. Maxtrees were unlimited, branches of zero length were collapsed and all multiple equally most parsimonious trees were saved. Estimated levels of homoplasy and phylogenetic signal (retention and consistency indices) were determined (Hillis \& Heuelsenbeck 1992). Branch and branch node support was determined using 1000 bootstrap replicates (Felsenstein 1985). Trees were rooted to Teratosphaeria nubilosa (CBS 116005).

The same aligned datasets were used for the Bayesian analysis, which was performed with MrBayes v. 3.2.6 (Ronquist \& Heuelsenbeck 2003) as implemented as Geneious plug-in after MrModeltest v. 3.5 (Nylander 2004) was used to determine the best nucleotide substitution model per gene region. For all gene regions the Hasegawa, Kishino and Yano (HKY85) nucleotide substitution model with gamma (G) and proportion of invariable site (I) parameters was the best model. Two independent runs of Markov Chain Monte Carlo (MCMC) were run over 1100000 generations. The heating parameter was set at 0.2 and trees were saved each 1000 generations, resulting in 1100 trees. Burn-in was set 

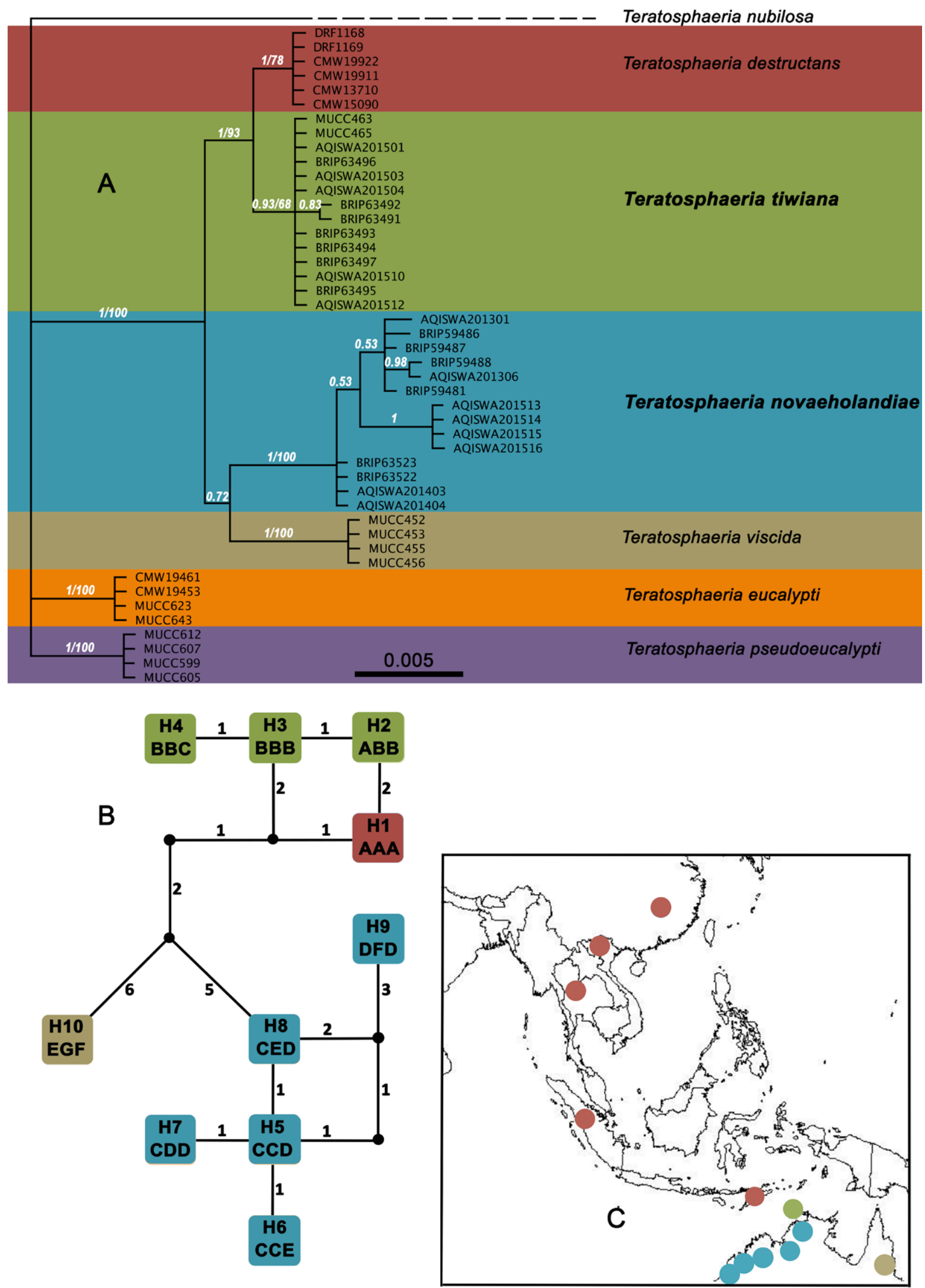

Fig. 1. A. Bayesian phylogram obtained from the combined ITS2, translation elongation factor $1-\alpha$ and the $\beta$-tubulin sequence alignment. Bootstrap support based on parsimony analysis and posterior probabilities of the branch nodes based on Bayesian analysis (italics) are given at the nodes. All trees are rooted to Teratosphaeria nubilosa. B. Haplotype network based on sequence data from ITS2, tub2 and tef1 gene regions. Colours following the blocks in Fig. 1. A indicate the isolates and the localities in Fig. 1. C. Red=T. destructans; Green=T. tiwiana; Orange=T. novaehollandiae; Brown=T. viscida C. Map showing collection localities of species described with colour coding aligned to the phylogram (Fig. $1 \mathrm{~A})$ and haplotype network (Fig. $1 \mathrm{~B})$. 


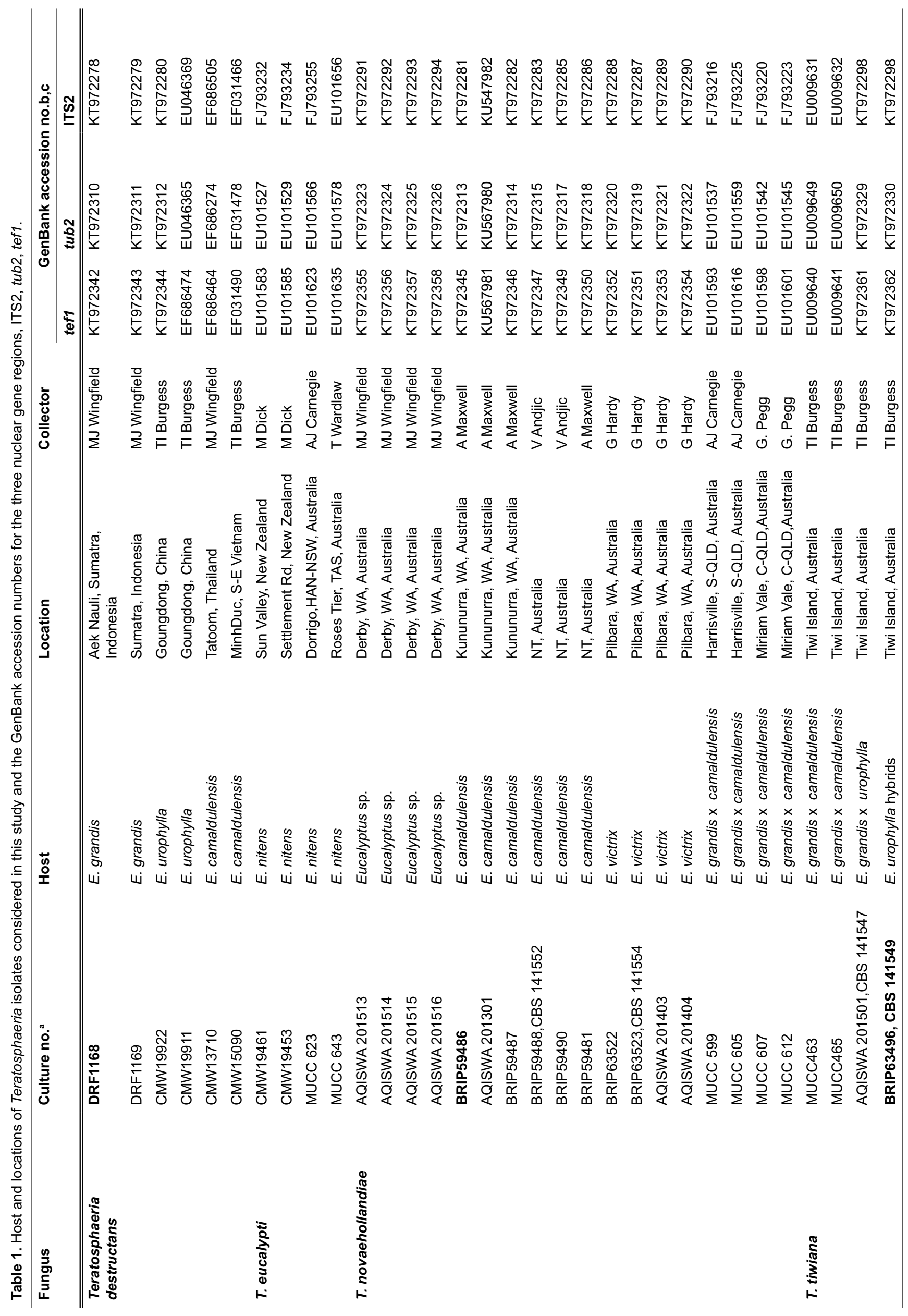




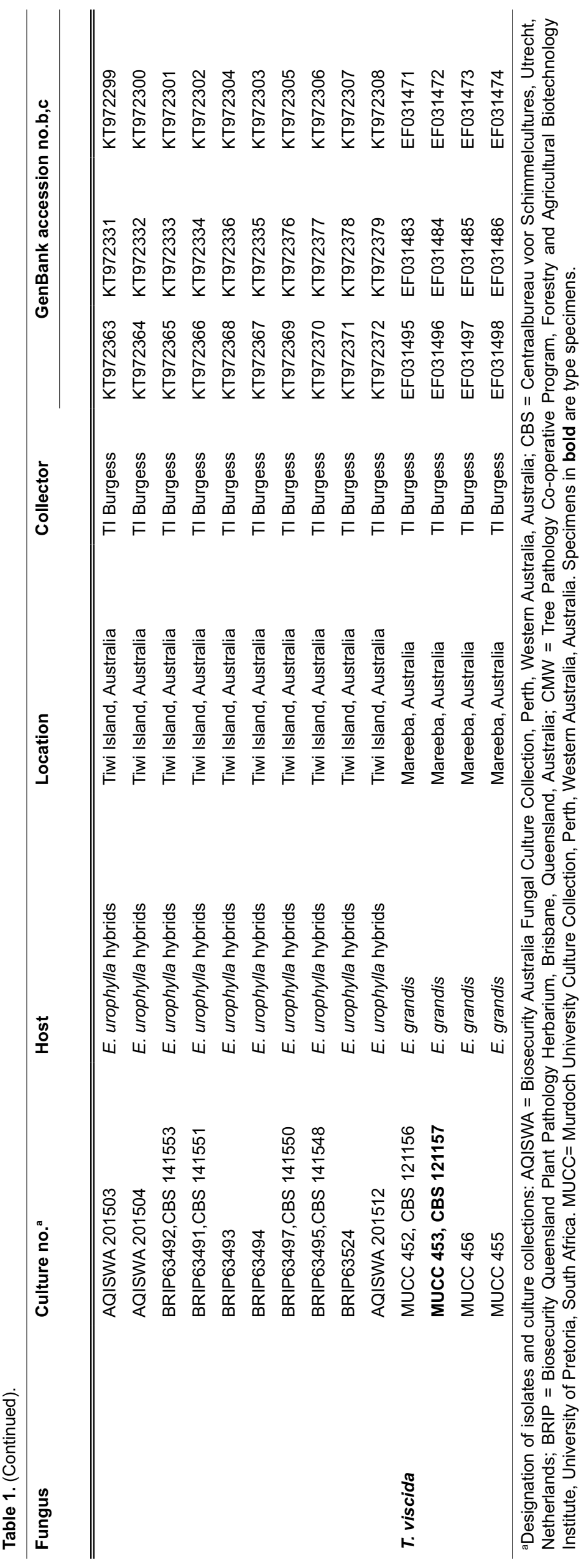

at 100000 generations (i.e. 100 trees), well after the likelihood values converged to the stationery, leaving 1000 trees from which the consensus trees and posterior probabilities were calculated.

Sequences obtained from this study have been deposited in GenBank and accession numbers are shown in Table 1. The sequence alignment was lodged in TreeBASE (www.treebase.org/) and taxonomic novelties in MycoBank (www.MycoBank. org).

\section{Haplotype network estimation}

Haplotype networks were used to compare isolates in order to infer which isolates were most closely related to one another. Haplotype networks were generated using the statistical parsimony method in the TCS v. 1.21 software programme (Clement et al. 2000). The program collapses DNA sequences into haplotypes and calculates the frequencies of haplotypes in the sample, which are used to estimate haplotype out-group probabilities that correlate with haplotype age (Donelly \& Tavare 1986, Castelloe \& Tempelton 1994). It then calculates an absolute distance matrix from which it estimates phylogenetic networks using a probability of parsimony, until the probability exceeds 0.95 (Templeton et al. 1992). The analysis was performed on the combined dataset of ITS2, tub1 and tef1 DNA sequences.

\section{RESULTS}

\section{Morphological identification}

The fungal isolates obtained in this study were characterised as slow-growing cultures on MEA. Morphological characteristics of the conidia of the Teratosphaeria isolates were similar in pigmentation, length, size, shape, and septa number (Table 2). Conidia were hyaline, subhyaline to pale brown, straight to variously curved, with 0-3 septa, and ranging from $30-50 \times 2-3.5 \mu \mathrm{m}$ (in vivo). These characteristics are typical for all Teratosphaeria species with kirramyces-like long conidia isolated from Eucalyptus. Morphological features of Teratosphaeria asexual morphs with long and short conidia are variable and not reliable for species separation, therefore the identification of those species relies on DNA sequencing (Andjic et al. 2007c, 2010b).

\section{Molecular identification and phylogenetic analysis}

A BLASTn search was conducted in GenBank to compare the ITS2 sequences of the Teratosphaeria isolates being examined in this study with those already there. The returned sequences were most similar to $T$. destructans (for isolates from Tiwi Island) and $T$. viscida (for isolates from Western Australia, WA, and Northern Territories, NT) and these and other less related species ( $T$. eucalypti and $T$. 
Table 2. Morphological features of conidia of Teratosphaeria destructans, T. viscida, T. novaehollandiae, and T. tiwiana species from eucalypts. In vivo $=$ herbarium specimens, in vitro $=$ isolates from culture, $\mathrm{n} / \mathrm{a}=$ not applicable (the isolates did not produce conidia in culture or were not available.)

\begin{tabular}{|c|c|c|c|c|c|c|c|}
\hline Fungus & $\begin{array}{l}\text { Specimen } \\
\text { number }\end{array}$ & Pigmentation & $\begin{array}{l}\text { Conidial } \\
\text { length (in } \\
\text { vivo) } \mu \mathrm{m}\end{array}$ & $\begin{array}{l}\text { Conidial } \\
\text { length (in } \\
\text { vitro) } \mu \mathrm{m}\end{array}$ & $\begin{array}{l}\text { Conidial } \\
\text { width (in } \\
\text { vivo) } \mu \mathrm{m}\end{array}$ & $\begin{array}{l}\text { Conidial } \\
\text { width (in } \\
\text { vitro) } \mu \mathrm{m}\end{array}$ & $\begin{array}{l}\text { Number } \\
\text { of septa }\end{array}$ \\
\hline \multicolumn{8}{|l|}{ T. destructans } \\
\hline Wingfield et al. 1992 & PREM54416 & Pale brown & $50-65$ & $\mathrm{n} / \mathrm{a}$ & $2.5-3$ & $\mathrm{n} / \mathrm{a}$ & $1-3$ \\
\hline Andjic et al. 2007 & PREM59261 & Pale brown & $38-47$ & $35-40$ & $2-2.5$ & $2-3$ & $1-3$ \\
\hline Andjic et al. 2007 & PREM59259 & Pale brown & $49-55$ & $33-40$ & $2-2.5$ & $2-2.5$ & $1-3$ \\
\hline \multicolumn{8}{|l|}{ T. viscida } \\
\hline \multicolumn{7}{|l|}{ T. novaehollandiae } & $0-3$ \\
\hline Present study & $\begin{array}{l}\text { BRIP59486 } \\
\text { Kununurra }\end{array}$ & Hyaline to subhyaline & $35-40$ & $30-35$ & $2.5-3$ & $2.0-2.8$ & $1-3$ \\
\hline Present study & $\begin{array}{l}\text { BRIP59488 } \\
\text { NT }\end{array}$ & Hyaline to subhyaline & $30-35$ & $25-30$ & $2.0-3$ & $1.5-2.0$ & $1-3$ \\
\hline Present study & $\begin{array}{l}\text { BRIP63523 } \\
\text { Pilbara }\end{array}$ & Hyaline to pale brown & $25-30$ & $26-30$ & $3-3.5$ & $2.3-2.8$ & $1-2$ \\
\hline $\begin{array}{l}\text { Present study } \\
\text { T. tiwiana }\end{array}$ & AQISWA201513 & Subhyaline to pale brown & $45-50$ & $\mathrm{n} / \mathrm{a}$ & $2.5-3$ & $\mathrm{n} / \mathrm{a}$ & $1-3$ \\
\hline Present study & BRIP63496 & Pale brown & $35-40$ & $35-40$ & $2.5-3$ & $2.5-3$ & $1-2$ \\
\hline
\end{tabular}

pseudoeucalypti) were used in the phylogenetic analyses. The aligned combined data set of ITS2, tub2, and tef1 consisted of 870 characters, of which 72 were parsimonyinformative and were used in the analysis. The partition homogeneity test showed no significant difference $(P>0.01$; $P=0.32$ ) between data from different gene regions, and so these data were combined. These data contained significant phylogenetic signal $(P<0.01 ; \mathrm{gl}=-0.95)$. Heuristic searches of unweighted characters in PAUP resulted in 18 equally most parsimonious trees of 91 steps $(\mathrm{Cl}=0.89, \mathrm{RI}=0.98$; TreeBASE S18826; Fig. 1). The Bayesian analysis resulted in a tree with the same topology and clades as those revealed in the parsimony analysis and presented as Fig. 1A (TreeBASE S18826; Fig. 2). In the Bayesian analysis, the tub2, tef1 and ITS2 regions consisted of 47,55 and 31 unique site patterns respectively.

The phylogeny generated from the combined alignment (Fig. 1A) resulted in three major clades: the first major clade comprising $T$. destructans and isolates from Tiwi Island with $93 \%$ bootstrap support and a Bayesian posterior probability of 1.0; the second comprising isolates from WA and the NT with $100 \%$ bootstrap support and a Bayesian posterior probability of 1.0; and the third containing isolates of T. viscida with 100 $\%$ bootstrap support and a Bayesian posterior probability of 1.0. Furthermore, the first major clade was subdivided in two sub-clades, one containing isolates of $T$. destructans and the second containing Teratosphaeria isolates from Tiwi Island. The T. destructans sub-clade was well supported with 78 $\%$ bootstrap support and a Bayesian posterior probability of 1.0. The Tiwi Island isolates subclade was supported with $68 \%$ bootstrap support and a strong Bayesian posterior probability of 0.93 . Although the bootstrap support for isolates from Tiwi Island was relatively low, posterior probability was strong for that node and the tree topology was consistent in all 18 equally most parsimonious trees. Teratosphaeria isolates from Tiwi Island were monophyletic in all 18 equally most parsimonious trees and consistently separated from $T$. destructans (data not shown).

The second clade containing isolates from WA and NT was well supported with a $100 \%$ bootstrap value and a posterior probability of 1.0 . The unnamed Teratosphaeria from this clade was closely related to, but phylogenetically distinct from $T$. viscida (Fig 1A). Isolates of both $T$. viscida and the undescribed Teratosphaeria were monophyletic with some sequence variation observed amongst new Teratosphaeria isolates. There were 12 fixed polymorphic sites distinguishing T. viscida from the new Teratosphaeria across the three gene regions indicating that isolates from this clade represent a new taxon (Table 3).

\section{Haplotype network}

Haplotype networks constructed in TCS software resulted in ten haplotypes $(\mathrm{H}-1-\mathrm{H}-10)$ amongst the isolates used in this study (Fig. 1B): Teratosphaeria destructans was represented by one haplotype, $\mathrm{H}-1$ (six isolates from Asia, AAA); T. tiwiana from Tiwi Islands was represented by three haplotypes $(\mathrm{H}-2$, two isolates, $A B B ; H-3$, six isolates, BBB; and $\mathrm{H}-4$, six isolates $\mathrm{BBC}$ ); the new Teratosphaeria isolates were represented by five haplotypes: $\mathrm{H}-5$ (two isolates from the Kimberly region in WA and one from the NT, CCD); $\mathrm{H}-6$ (one isolate from the NT, CCE); $\mathrm{H}-7$ (two isolates from the NT, CDD); $\mathrm{H}-8$ (four isolates from the Pilbara, WA, CED); 

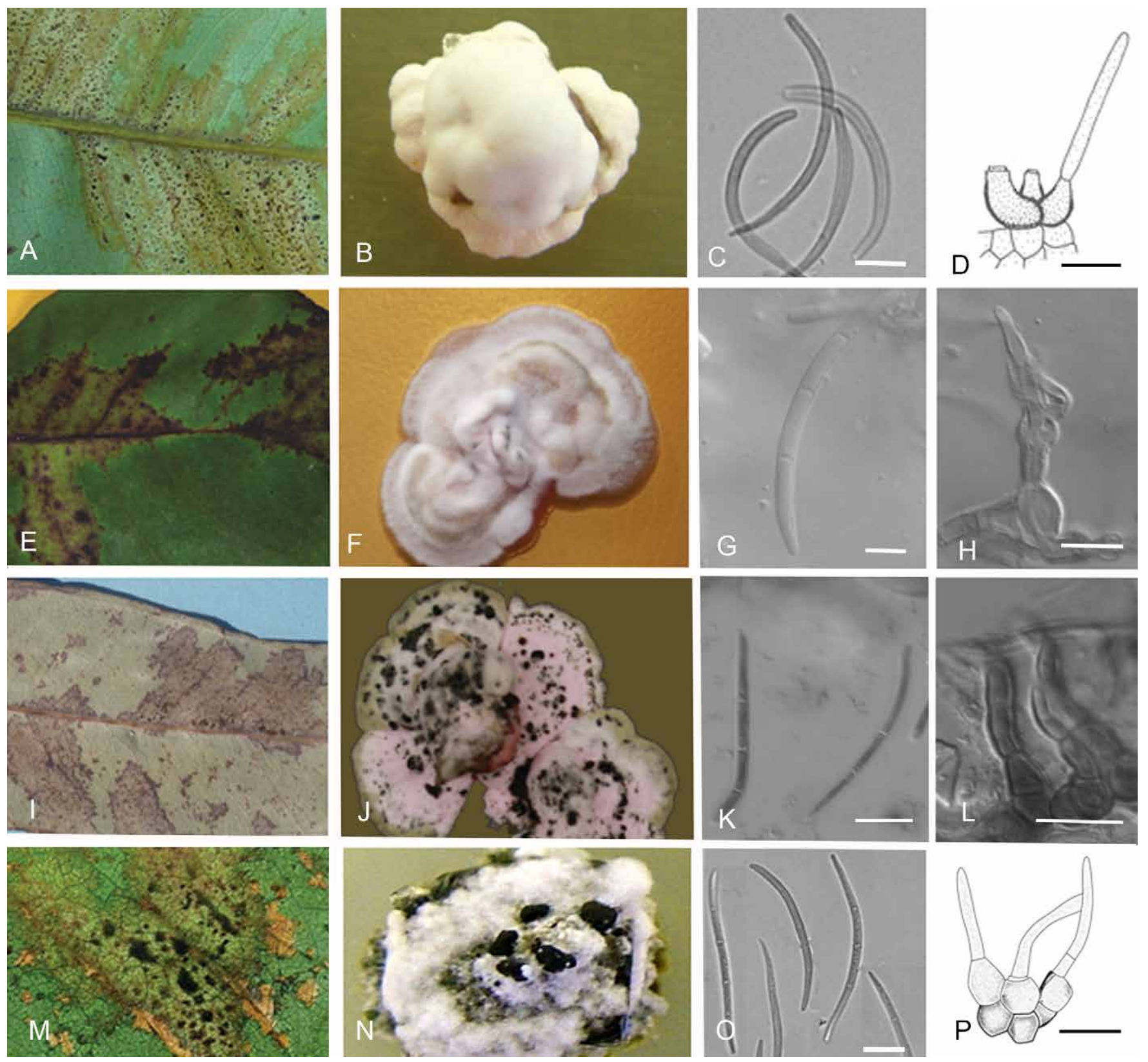

Fig. 2. Morphological features of Teratosphaeria destructans, T. tiwiana, T. novaehollandiae, and T. viscida from eucalypts. A-D. T. destructans specimen PREM 59261(CMW 17919). A. Leaf symptoms. B. Culture morphology on MEA. C. Conidia morphology. D. Conidiogenous cells and conidiogenesis. E-H. T. tiwiana holotype specimen and ex type culture BRIP 63496 (CBS 141549). E. Leaf symptoms. F. Culture morphology on MEA. G. Conidia morphology. H. Conidiogenous cells and conidiogenesis. I-L. T. novaehollandiae holotypespecimen and ex type culture BRIP 59486. I. Leaf symptoms. J. Culture morphology on MEA. K. Conidia morphology. L. Conidiogenous cells and conidiogenesis. M-P. T. viscida specimen BRIP 49804 CBS 121156). M. Leaf symptoms. N. Culture morphology on MEA. O. Conidia morphology. P. Conidiogenous cells and conidiogenesis. Bars $=10 \mu \mathrm{m}$.

and $\mathrm{H}-9$ (four isolates from Derby, WA, DFD); and T. viscida was represented by one haplotype, $\mathrm{H}-10$ (four isolates from Queensland, EGF).

Three different haplotypes $(\mathrm{H}-2, \mathrm{H}-3, \mathrm{H}-4)$ were observed in the population from Tiwi Island, but none of them were shared with the phylogenetically closely related $T$. destructans $(\mathrm{H}-1)$.

Five haplotypes were detected in the population from WA and NT. Only one haplotype was shared among isolates from WA and the NT (H-5), and none of the haplotypes were shared with the closely related $T$. viscida $(\mathrm{H}-10)$.
Morphological examination did not show any major differences between the Teratosphaeria isolates obtained in this study. This situation is common in species lacking a known sexual morph. However, the combination of phylogenetic inference and haplotype analysis provides robust evidence that isolates from Tiwi Island, NT and WA are distinct from both $T$. destructans and $T$. viscida. They are therefore described as new species here. 
Table 3. Polymorphic nucleotides from sequence data of ITS2, tef1 and tub2 gene regions showing the variation between isolates of Teratosphaeria viscida and T. novaehollandiae. Ex-type cultures are indicated in bold face.

\begin{tabular}{|c|c|c|c|c|c|c|c|c|c|c|c|c|}
\hline & \multicolumn{5}{|c|}{ tub2 } & \multicolumn{5}{|c|}{ tef1 } & \multicolumn{2}{|c|}{ ITS2 } \\
\hline & 96 & 99 & 105 & 229 & 158 & 166 & 169 & 173 & 209 & 211 & 181 & 183 \\
\hline \multicolumn{13}{|c|}{ Teratosphaeria viscida } \\
\hline CBS 121156 & G & A & G & $\mathrm{T}$ & $\mathrm{T}$ & G & A & A & G & G & $\mathrm{T}$ & G \\
\hline CBS 121157 & G & A & G & $\mathrm{T}$ & $\mathrm{T}$ & G & $A$ & $A$ & G & G & $\mathrm{T}$ & G \\
\hline MUCC 456 & G & A & G & $\mathrm{T}$ & $\mathrm{T}$ & G & $A$ & $A$ & G & G & $\mathrm{T}$ & G \\
\hline MUCC 455 & G & $A$ & G & $\mathrm{T}$ & $\mathrm{T}$ & G & $A$ & $A$ & G & G & $\mathrm{T}$ & G \\
\hline \multicolumn{13}{|c|}{ Teratosphaeria novaehollandiae } \\
\hline BRIP59486 & A & G & $\mathrm{T}$ & C & C & $A$ & C & $\mathrm{T}$ & A & $A$ & C & C \\
\hline BRIP59488 & A & G & $\mathrm{T}$ & C & C & A & C & $\mathrm{T}$ & A & $A$ & $C$ & C \\
\hline BRIP63523 & A & G & $\mathrm{T}$ & C & C & A & C & $\mathrm{T}$ & A & $A$ & C & C \\
\hline BRIP63523 & A & G & $\mathrm{T}$ & C & C & A & C & $\mathrm{T}$ & A & $A$ & C & C \\
\hline AQISWA201513 & A & G & $\mathrm{T}$ & C & C & A & C & $\mathrm{T}$ & A & A & C & C \\
\hline
\end{tabular}

\section{TAXONOMY}

Teratosphaeria novaehollandiae V. Andjic, T.I. Burgess, A. Maxwell, sp. nov. MycoBank MB815681

(Fig. 2I-L)

Etymology: Name refers to original Dutch name for the geographic western half of Australia, where the fungus was collected.

Diagnosis: Distinguished from T. viscida (cfr. Figs. 2 I-L and 2 $\mathrm{M}-\mathrm{P}$ ) in not producing highly hydrophobic and viscous spore masses. In vivo, T. novaehollandiae produces shorter conidia (33-40 $\mu \mathrm{m})$ than those of $T$. viscida $(47-60 \mu \mathrm{m})$. In vitro, $T$. novaehollandiae produce shorter conidia $(27-31 \mu \mathrm{m})$ than T. viscida $(35-40 \mu \mathrm{m})$. Unlike $T$. viscida, $T$. novaehollandiae does not produce a synasexual morph with chlamydosporelike structures in culture. Based on phylogenetic analyses of sequence data obtained for the ITS2, tef1 and tub2 gene regions, $T$. novaehollandiae has 12 fixed polymorphic sites across three gene regions which distinguish it from the closely related $T$. viscida (Table 3 ).

Type: Australia: Western Australia: Kununurra, isolated from leaves of Eucalyptus camaldulensis, Apr. 2012, A. Maxwell \& V. Andjic (BRIP 59486 - holotype).

Description: Leaf spots circular to irregular, $2.5-35 \mathrm{~mm}$ diam, single to confluent, pale to medium brown with a red brown border on the top surface, and light brown from below. Conidiomata pycnidial, hypophyllous, single, dark brown to black. Conidiophores reduced to conidiogenous cells. Conidia solitary, 1-3-septate, hyaline to pale brown, slightly verruculose, cylindrical, straight to slightly curved, thickwalled, base truncate sometimes with marginal frill, apex obtuse, $(20-) 33-40(-62) \times(1.5-) 2-3.5(-4.0)$ (mean $=38 \times$ $2.5 \mu \mathrm{m})$.

Culture characteristics: Colonies $35 \times 25 \mathrm{~mm}$ after $1 \mathrm{mo}$ at $25^{\circ} \mathrm{C}$ in the dark on MEA, white 5 YR $8 / 1$ to pink 5 YR $8 / 4$ on the upper surface, olive grey 5YR 7/1 on reverse. Mycelium subhyaline to pale brown, septate, branched. Conidiomata pycnidial, single, dark brown to black, globose to subglobose, unilocular: wall of textura angularis. Conidiogenous cells not seen in culture. Conidia solitary, 1-3-septate but mostly 3-septate, hyaline to subhyaline, slightly verruculose, cylindrical, straight to slightly curved (22-)27-30(-41) $\times(1-$ 2-2.5(-4) (mean $=30 \times 2.5 \mu \mathrm{m})$.

Additional material examined: Australia: Western Australia and Northern Territory: Kununurra and Bachelor, isolated from $E$. camaldulensis, Apr. 2012, A. Maxwell \& V. Andjic (BRIP 59487, BRIP 59488 = CBS 141552, BRIP 59490, and BRIP 59481); Western Australia: Pilbara isolated from Eucalyptus victrix, Aug. 2013, G. Hardy (BRIP 63522, BRIP 63523 = CBS 141554, AQISWA 201403, AQISWA 201404); Derby, isolated from leaves of Eucalyptus sp., July 2006, T.I Burgess \& M.J. Wingfield (BRIP 64754, culture not viable).

Teratosphaeria tiwiana V. Andjic, T.I. Burgess, A. Maxwell, sp. nov.

MycoBank MB815680

(Fig. 2 E-H)

Etymology: Named after Tiwi Island, the type locality.

Diagnosis: Distinguished from T. destructans (cfr.Fig. $2 \mathrm{E}-\mathrm{H}$ v. A-D) by producing slightly shorter conidia and in septa number. In vivo, T. tiwiana produces shorter and less curved conidia $(35-40 \mu \mathrm{m})$ than those of $T$. destructans $(38-65 \mu \mathrm{m})$. In contrast to $T$. destructans, whose conidia is 1-3-septate, the conidia of $T$. tiwiana are 1-2-septate (Fig. 2C, G). Based on multi-gene phylogeny $T$. tiwiana can be distinguished from $T$. destructans with 6 bp differences across three gene regions.

Type: Australia: Northern Territory: Tiwi Island, isolated from leaves of Eucalyptus hybrids E. grandis $\times E$. urophylla, Aug. 2007, T.I. Burgess (BRIP 63496- holotype; BRIP $63496=$ CBS 141549- ex-type cultures). 
Description: Leaf spots circular to irregular, 3-20 mm diam, single to confluent, pale to medium brown with red brown border on the top surface, light brown below. Conidiomata pycnidial, hypophyllous, single, dark brown. Conidiophores reduced to conidiogenous cells. Conidia solitary, 1-2-septate, predominantly with 1-septum, pale brown, slightly verruculose, cylindrical, straight to variously curved, thick-walled, base truncate, sometimes with marginal frill, apex obtuse, (26.5-)35$40(-44.5) \times(2-) 2.5-3.0(-3.5)($ mean $=35 \times 2.8 \mu \mathrm{m})$.

Culture characteristics: Colonies $25 \times 25 \mathrm{~mm}$ after $1 \mathrm{mo}$ at $25^{\circ} \mathrm{C}$ in the dark on MEA, white 5 YR $8 / 1$ to pink 5 YR $8 / 4$ on the upper surface, olive grey $5 Y R$ 7/1 on reverse. Mycelium subhyaline to pale brown, septate, branched. Conidiomata, if present, pycnidial, single, dark brown to black, globose to subglobose, unilocular: wall of textura angularis. Conidiogenous cells not seen in culture. Conidia solitary, 0-1-septate, subhyaline to pale brown, slightly verruculose, cylindrical, straight to variously curved (25-)35-40(-56.5) $\times(2-) 2.5-3(-3.5)($ mean $=38 \times 3.0 \mu \mathrm{m})$, lateral branches occasionally present as secondary conidia.

Additional specimens examined: Australia: Northern Territory: Tiwi Island, isolated from E. grandis and E. urophylla hybrids, Aug. 2007, T.I. Burgess (BRIP $63492=$ CBS 141553, BRIP $63491=$ CBS 141551, BRIP 63493, BRIP 63494, BRIP $63497=$ CBS 141550, BRIP 63495 = CBS 141548, BRIP 63524).

\section{DISCUSSION}

We describe two new cryptic Teratosphaeria species isolated from Eucalyptus in northern Australia: T. tiwiana and $T$. novaehollandiae. Australian isolates previously described as $T$. destructans were re-examined and are here assigned to these two new taxa. Teratosphaeria destructans s. str., therefore, has not been correctly recorded in Australia, and remains restricted to South-East Asia and Africa.

The two new Teratosphaeria species could not be morphologically distinguished, thus the description was based on data inferred from multi-gene phylogeny: applying the Genealogical Concordance for Phylogenetic Species Recognition (GCPSR; Taylor et al. 2000) criteria, and noting the haplotype analysis of combined sequence data for the ITS2, tub2 and tef1 gene regions. The GCPSR concept uses the phylogenetic concordance of multiple unlinked genes to indicate a lack of genetic exchange and thus evolutionary independence of lineages (Geiser et al. 1998, Taylor et al. 2000, Starkey et al. 2007, Cai et al. 2011). It is a useful criterion for the discrimination of species when other species recognition criteria (morphological, physiological, reproduction, host specificity) fail (Cai et al. 2011). GCPSR has already proved to be a valuable tool for recognising cryptic species in Colletotrichum, Diaporthe, Phyllosticta, and Fusarium species complexes (Glienke et al. 2011, Damm et al. 2012, Shivas \& Cai 2012, Gomes et al. 2013, Hansen \& Olariaga 2015).

Teratosphaeria tiwiana, a cryptic species similar to $T$. destructans, was isolated from non-endemic juvenile eucalypt leaves from a clonal taxa trial from Tiwi Island, NT, Australia.
Previously, based on symptoms, conidial morphology and multilocus sequence data, the isolates from Tiwi Island had been identified as $T$. destructans although they grouped separately from $T$. destructans from Asia (Burgess et al. 2007). As a consequence, T. destructans was removed from the NAQS target list for exotic invasive plant pathogens. This study included more isolates from Tiwi Island than the initial study, and re-evaluated the relationship between Australian and Asian isolates using multi-locus sequence data and haplotype analysis. The DNA sequence analysis obtained in this study was in agreement with the findings in Burgess et al. (2007); there were 6 bp differences amongst isolates across three gene regions. In that previous study, it was thought that 6 bp difference was within the normal limits of infraspecies variation and the isolates from Australia were identified as T. destructans However, multigene phylogeny and haplotype analysis obtained in the present study provided sufficient evidence to support the separation of Australian isolates as a separate species described here as T. tiwiana. According to the Genealogical Concordance Concept of Dettman et al. (2003), a clade is recognised as an independent evolutionary lineage if the clade was present in the majority of the single locus genealogies and the clade is identified from the majority rule consensus tree regardless of its bootstrap or posterior probability support. In this study, the T. tiwiana clade was recovered in all three single strict consensus trees satisfying the criterion of genealogical concordance (data not shown); the clade was monophyletic in the phylogenetic trees inferred from single gene regions and from the combined dataset; and the lineage was supported by Bayesian analyses. Furthermore, T. tiwiana isolates showed sequence variation and were split in three haplotypes, while the sequences of $T$. destructans isolates were identical and contained only one haplotype. The haplotypes were not shared between these two species. This suggests that $T$. tiwiana is an endemic Australian cryptic species.

Teratosphaeria novaehollandiae was found on amenity plantings of an unidentified native Eucalyptus species in Derby, endemic E. camaldulensis woodlands in northern WA and the NT, and on E. victrix in the Pilbara, WA. These isolates were collected from adult and juvenile eucalypt foliage across an extensive area of northern Australia and where present caused minor to moderate levels of damage to Eucalyptus leaves. The sequences of $T$. novaehollandiae were variable and split into five haplotypes. Two haplotypes contained isolates from northern WA, one haplotype contained isolates from NT, one contained isolates from Pilbara and one contained isolates from Derby, WA. Despite having unique haplotypes, isolates from across northern WA and the NT could not be consistently split into separate phylogenetic species.

In a previous study, based on conidial morphology and phylogenetic analysis, isolates from Derby (WA) were assigned to T. destructans (Burgess et al. 2007). We have now re-evaluated the taxonomic position of the Derby isolates using multigene sequence data including haplotype analysis. The results obtained in this study have demonstrated that all isolates from Derby grouped together and were separated from Asian and Australian isolates previously named as $T$. destructans (i.e. T. tiwiana). The Derby isolates clustered 
within the $T$. novaehollandiae clade, which was well supported (1.00 Posterior probabilities) and was distinct from both $T$. destructans and T. viscida. The Derby isolates were not consistently separated from other isolates within $T$. novaehollandiae and are therefore here recognised as the new cryptic species $T$. novaehollandiae.

Sequence data and ex-type cultures are now available for for eight Teratosphaeria species described from eucalypts and for which a kirramyces-like asexual morph is known. Conidia range in size from the shortest $T$. novaehollandiae $(33-40 \mu \mathrm{m})$ to the longest, $T$. destructans (50-65 $\mu \mathrm{m})$, pigmentation and septation also varies, but generally conidia are septate. These species produce lesions on leaves with various symptoms. All except $T$. destructans have been reported in Australia. The expansion of eucalypt plantation forestry into the subtropics of Australia has led to the discovery of many new Teratopshaeria species, and it appears to be the dominant fungal genus on subtropical eucalypt leaves. Currently, the two species newly described in this study are not causing any significant damage to Australian eucalypt plantations, but the threat they may pose to the forestry industry is unknown.

\section{ACKNOWLEDGEMENTS}

This work was funded in part by the Australian Research Council DPO343600 "Population genetics of fungal pathogens that threaten the biosecurity of Australia's eucalypts". We also thank Dianne White for technical assistance.

\section{REFERENCES}

Andjic V, Barber PA, Pegg GS, Carnegie AJ, Hardy GEStJ et al. (2007b) Kirramyces viscidus sp. nov, a new eucalypt pathogen from tropical Australia is closely related to the serious leaf pathogen, Kirramyces destructans. Australasian Plant Pathology 36: 478-487.

Andjic V, Barber PA, Carnegie AJ, Hardy GEStJ, Wingfield MJ et al. (2007c) A morphological and phylogenetic reassessment of the genus Phaeophleospora and the resurrection of the genus Kirramyces. Mycological Research 111: 1184-1198.

Andjic V, Cortinas MN, Hardy GEStJ, Burgess TI, Wingfield MJ (2007a) Multiple gene genealogies reveal important relationships between Phaeophleospora spp. infecting Eucalyptus leaves. FEMS Microbiology Letters 268: 22-33.

Andjic V, Dell B, Barber P, Hardy GEStJ, Wingfield MJ, et al. (2011) Plants for planting; indirect evidence for the movement of a serious forest pathogen, Teratosphaeria destructans, in Asia. European Journal of Plant Pathology 131: 49-58.

Andjic V, Pegg GS, Carnegie AG, Callister A, Hardy GEStJ et al. (2010a) Teratosphaeria pseudoeucalypti, new cryptic species responsible for leaf blight of Eucalyptus in subtropical and tropical Australia. Plant Pathology 59: 900-912.

Andjic V, Whyte G, Hardy GEStJ, Burgess TI (2010b) New Teratosphaeria species occurring on eucalypts in Australia. Fungal Diversity 43: 27-38.

Burgess TI, Andjic V, Hardy GEStJ, Dell B, Xu D (2006) First report of Phaeophleospora destructans in China. Journal of Tropical Forest Science 18: 144-146.
Burgess TI, Andjic V, Wingfield MJ, Hardy GEStJ (2007) The eucalypt leaf blight pathogen Kirramyces destructans discovered in Australia. Australasian Plant Disease Notes 2: 141-144.

Carnegie AJ (2007a) Forest health condition in New South Wales, Australia, 1996-2005. I Fungi recorded from eucalypt plantations during forest health surveys. Australasian Plant Pathology 36: 213-224.

Carnegie AJ (2007b) Forest health condition in New South Wales, Australia, 1996-2005. II Fungal damage recorded in eucalypt plantations during forest health surveys and their management. Australasian Plant Pathology 36: 225-239.

Carnegie AJ, Burgess TI, Beilharz V, Wingfield MJ (2007c) New species of Mycosphaerella in plantations and native forests in Eastern Australia. Mycologia 99: 461-474.

Cai L, Giraud T, Zhang N, Begerow D, Cai G et al. (2011) The evolution of species concepts and species recognition criteria in plant pathogenic fungi. Fungal Diversity 50: 121-133.

Castelloe J, Templeton AR (1994) Root probabilities for intraspecific gene trees under neutral coalescent theory. Molecular Phylogenetics and Evolution 3: 102-113.

Clement M, Posada D, Crandall KA (2000) TCS: A computer program to estimate gene genealogies. Molecular Ecology 9: 1657-1659.

Crous PW (2009) Taxonomy and phylogeny of the genus Mycosphaerella and its anamorphs. Fungal Diversity 38: 1-24.

Crous PW, Wingfield MJ, Mansilla JP, Alfenas AC, Groenewald JZ (2006) Phylogenetic reassessment of Mycosphaerella spp. and their anamorphs occurring on Eucalyptus II. Studies in Mycology 55: 99-131.

Crous PW, Groenewald JZ, Summerell BA, Wingfield BD, Wingfield MJ (2009a) Co-occurring species of Teratosphaeria on Eucalyptus. Persoonia 22: 38-48.

Crous PW, Summerell BA, Carnegie AJ, Wingfield MJ, Hunter GC et al. (2009b) Unravelling Mycosphaerella: do you believe in genera? Persoonia 23: 99-118.

Damm U, Cannon PF, Woudenberg JHC, Crous PW (2012) The Colletotrichum acutatum species complex. Studies in Mycology 73: $37-113$.

de Souza TC, de Silva AC, de Silva LMG, Ferraz HGM, Junior NB et al. (2014) Teratosphaeria pseudoeucalypti on eucalyptus in Brazil. Tropical Plant Pathology 39: 407-412.

Dettman JR, Jacobson DJ, Taylor JW (2003) A multilocus genealogical approach to phylogenetic species recognition in the model eukaryote Neurospora. Evolution 57: 2703-2720.

Dick M (1982) Leaf-inhabiting fungi of eucalypts in New Zealand. New Zealand Journal of Forestry Science 12: 525-537.

Felsenstein J (1985) Confidence intervals on phylogenetics: an approach using bootstrap. Evolution 39: 783-791.

Geiser DM, Pitt JI, Taylor JW (1998) Cryptic speciation and recombination in the aflatoxin-producing fungus Aspergillus flavus. Proceedings of the National Academy of Sciences, USA 95: 388-393.

Glienke C, Pereira OL, Stringari D, Fabris, J., Kava-Cordeiro et al. (2011) Endophytic and pathogenic Phyllosticta species, with reference to those associated with Citrus Black Spot. Persoonia 26: 47-56.

Gomes RR, Glienke C, Videira SIR, Lombard L, Groenewald JZ, Crous PW (2013) Diaporthe: a genus of endophytic, saprobic and plant pathogenic fungi. Persoonia 31:1-41.

Greyling I, Wingfield MJ, Coetzee Martin PA, Marincowitz Seonju, Roux J (2016) The Eucalyptus shoot and leaf pathogen 
Teratosphaeria destructans recorded in South Africa. Southern Forests: a Journal of Forest Science 78: 123-129.

Hansen K, Olariaga I (2015) Species limits and relationships within Otidea inferred from multiple gene phylogenies. Persoonia 35: 148-165.

Hillis DM, Huelsenbeck JP (1992) Signal noise and reliability in molecular phylogenetic analysis. Journal of Heredity 83: 189195.

Hunter GC, Wingfield BD, Crous PW, Wingfield MJ (2006) A multigene phylogeny for species of Mycosphaerella occurring on Eucalyptus leaves. Studies in Mycology 55: 147-161.

Hunter GC, Crous PW, Carnegie JA, Burgess IT, Wingfield MJ (2011) Mycosphaerella and Teratosphaeria diseases of Eucalyptus: easily confused and with serious consequences. Fungal Diversity 50: 145-166.

Miller JT, Cannon PG, Ecroyd CE (1992) Introduced forest trees in New Zealand: recognition, role, and seed source part 11. Eucalyptus nitens (Deane et Maiden) Maiden. New Zealand Ministry of Forestry, Forest Research Bulletin 124: 27-28.

Nylander JAA (2004) MrModeltest v2. Program distributed by the author. Uppsala: Evolutionary Biology Centre.

Old KM, Pongpanich K, Thu PQ, Wingfield MJ, Yuan ZQ (2003a) Phaeophleospora destructans causing leaf blight epidemics in South East Asia. In: 8th International Congress of Plant Pathology, Feb. Vol. 2 - Offered papers ICPP: 165, Christchurch, New Zealand.

Old KM, Wingfield MJ, Yuan ZQ (2003b) A Manual of Diseases of Eucalypts in South-East Asia. Bogor: Centre for International Forestry Research.

Park RF, Keane PJ, Wingfield MJ, Crous PW (2000) Diseases and pathogens of eucalypts. In: Fungal Diseases of Eucalypt Foliage (Keane PJ, Kile GA, Podger FD, Brown BN, eds): 153-240. Melbourne: CSIRO Publishing.

Ramos SO, Perez CA (2015) First report of Teratosphaeria pseudoeucalypti on Eucalyptus hybrids in Argentina. Plant Disease 99: 554.
Ronquist F, Heuelsenbeck JP (2003) MrBayes 3: Bayesian phylogenetic inference under mixed models. Bioinformatics 19: 1572-1574.

Sankaran KC, Sutton BC, Minter DW (1995) A checklist of fungi recorded on eucalypts. Mycological Papers 170: 1-375.

Shivas RG, Cai L (2012) Cryptic fungal species unmasked. Microbiology Australia 1: 36-37.

Soria S, Alonso R, Bettucci L, Lupo S (2014) First report of Teratosphaeria pseudoeucalypti in Uruguay. Australasian Plant Disease Note 9: 146.

Starkey DE, Ward TJ, Aoki T, Gale LR, Kistler HC, et al. (2007) Global molecular surveillance reveals novel Fusarium head blight species and trichothecene toxin diversity. Fungal Genetics and Biology 44: 1191-1204.

Swofford DL (2003) PAUP*: phylogenetic analysis using parsimony ( ${ }^{*}$ and other methods). Version 4.0b10. Sunderland, MA: Sinauer Associates.

Taylor JW, Jacobson DJ, Kroken S, Kasuga T, Geiser DM et al. (2000) Phylogenetic species recognition and species concepts in fungi. Fungal Genetics and Biology 31: 21-32.

Templeton AR, Crandall KA, Sing CF (1992) A cladistic analysis of phenotypic associations with haplotypes inferred from restriction endonuclease mapping and DNA sequence data III. Cladogram estimation. Genetics 132: 619-633.

Taole M, Bihon W, Wingfield B, Wingfield MJ, Burgess TI (2015) Multiple introductions from multiple sources: Invasion patterns for an important Eucalyptus leaf pathogen. Ecology and Evolution 5: $1-11$.

Walker J, Sutton BC, Pascoe IG (1992) Phaeoseptoria eucalypti and similar fungi on Eucalyptus with description of Kirramyces gen. nov. (Coelomycetes). Mycological Research 96: 911-924.

Wingfield MJ, Crous PW, Boden D (1996) Kirramyces destructans sp. nov., a serious leaf pathogen of Eucalyptus in Indonesia. South African Journal of Botany 62: 325-327. 